This is a self-archived version of an original article. This version may differ from the original in pagination and typographic details.

Author(s): Jyrkinen, Marjut; Väkiparta, Maria; Lämsä, Anna-Maija

Title: Care and gendered work in reception centers in Finland

Year: 2020

Version: Accepted version (Final draft)

Copyright: @ Emerald Publishing Limited 2020

Rights: In Copyright

Rights url: http://rightsstatements.org/page//nC/1.0/?language=en

Please cite the original version:

Jyrkinen, M., Väkiparta, M., \& Lämsä, A.-M. (2020). Care and gendered work in reception centers in Finland. Equality, Diversity and Inclusion, 39(2), 166-180.

https://doi.org/10.1108/EDI-10-2018-0192 


\title{
Care and Gendered Work in Reception Centers in Finland
}

Jyrkinen, Marjut - Väkiparta, Maria - Lämsä, Anna-Maija 2020. Care and Gendered Work in Reception Centers in Finland. Equality, Diversity and Inclusion: An International Journal 29(2), 166-180.

\begin{abstract}
:
Purpose: This article focuses on how gendered processes of working life are (re)constructed but also challenged discursively in paid and volunteer care and work in reception centers. The purpose is to show how caring work with asylum seekers can both enhance the traditional gender order and challenge it through enabling men to have opportunities to care.

Design: The data was produced through qualitative interviews among paid workers and volunteers in reception centers, and analyzed through a discourse analysis approach.

Findings: Three discourses of care and work were identified: a discourse on solidarity and care; a discourse on control and order; and a discourse on caring men. The findings show that traditional attitudes towards gender are easily discerned in other cultures, but not as easily recognized in the everyday processes near at hand. Gender order is retained through traditional roles, which also reflects conventional attitudes in a society often seen as a model country for equality. However, change is possible, and one core issue is the need to involve men in care work and caring in general.

Social implications: Our findings can be applicable to the deconstruction of traditional gender order in working life; to the disclosure of gendered xenophobia in work with asylum seekers, in particular through dialogue with 'Others'; and to the enabling of care by men.

Originality/value: Little previous research has been done on care in reception centers and care as a gendered activity with value. In the future many countries are likely to encounter increases in asylum seekers, and therefore intersections of gender and ethnicity are of importance in societies as regards migration, work, and care.
\end{abstract}

Key words: care, work, gender, gender order, asylum seekers, reception centers, men, masculinities, Finland

\section{Introduction}

Our article addresses how gendered processes of working life are (re)constructed but also challenged discursively in paid and volunteer care and work in reception centers. Our analysis reveals embedded gendered and racialized attitudes in Finnish society, although Finland scores high in international evaluations on gender equality (for instance, World Economic Forum, 2017). Many omissions relate to working life, care, and caring. We argue that the care of and work with 'Others' can enhance a new understanding of care, which not only includes women but men as well, thereby changing the gender order (Connell, 1987) and diminishing xenophobia.

Manifold crisis and unrest in the Middle East, Afghanistan, and the African region are tightly connected to the colonial histories and neo-colonial abuses of the Global North and West, and unequal globalization processes. Migration has intensified, and in recent years also many Nordic countries have received remarkably more asylum seekers than ever before. Neo-nationalism and right-wing populism have gained ground through neoliberal austerity policies and cuts in social security in many countries like Finland (Keskinen, 2012; Keskinen and Andreassen, 2017; see Bassel and Emejulu, 2018). Despite the fact that our research addresses work in reception centers, our focus is not on questions concerning refugees, asylum seeking, or its policies per se. Instead, our research interest is twofold: firstly, to examine how gendered discourses are (re)constructed in work and care with Others, and secondly, to explore their impact on gender order and masculinity norms as regards care. The intersection of ethnicity and gender is an experimental laboratory for analyzing the work and 
care in reception centers. Exploring processes of work and care in a particular societal context where gender and ethnicity intersect, such as in the reception centers and during crises, enables a critical evaluation of the embedded traditional gender order.

We draw from earlier feminist research on care and care ethics (Gilligan, 1982; Tronto, 1993; Bowlby et al. 2010) and research on gender and care in critical studies on men and masculinities (for instance, Pringle, 1995; Hearn, 2001; Campbell and Carroll, 2017; Hanlon, 2012). We aim to contribute to discussions and research on gendered (care) work. We seek spaces for broadening the scope of the discussion on 'men's care' in intimate relations to working life contexts.

\section{The Reception Centers as the Context}

The rapid increase in people searching for asylum in 2015-16 provoked widespread public and political debate in Europe, including Finland, where approximately 40,000 people sought asylum during that time; the previous number had been a maximum of 6,000 people per year (Migri, 2017; Jauhiainen, 2017). The debates became inflamed in the media, social media in particular, where the situation was described as "an asylum seeker flood," "a refugee crisis," where profit-seeking "iPhone men" or even "criminals" were suspiciously arriving in the country. A clear division line emerged: citizens and politicians who were critical of asylum seekers and also more generally toward migration to Finland, and those who welcomed asylum seekers and emphasized the aspects of human rights and the obligations to help those living under threat.

Establishing reception centers and recruiting for the work positions took place at a fast tempo in 2015 in Finland. Many reception centers were built, and almost 10,000 Finnish people volunteered to help the asylum seekers. In the emergency, there was no systematic, long-term education concentrated specifically on work with asylum seekers. Those who were recruited had many different educational backgrounds in social and care work, but also in other fields.

The operations of the reception centers are regulated by a law that guarantees a minimum livelihood for the asylum seekers and supports their well-being during the refugee application process, which often takes over one year-in 2016 the average time was eight months (Ministry of the Interior 2017). According to Migri, the Finnish Immigration Service (2017b), the purpose of the reception center services is to provide the basic services needed by the asylum seekers. They highlight that "[f]or the services to be provided it is important that you comply with the reception center rules and safety regulations." Thus, the centers are both "homes" for the asylum seekers and at the same time institutions that operate through multi-level governance: the state level (legislation), the regional level (Regional Centers for Economic Development, Transport and the Environment, ELY centers), the local level (municipalities and their authorities), and the level of the actual organizers of the centers and their staff. The rules and instructions of the centers may vary, but they define the everyday life of the residents.

In the centers, people are expected to follow Finnish law and encoded cultural behavioral rules. These often hidden and embedded codes are important for asylum seekers to know in order to cope in the new context. These unspoken expectations are not necessarily clear nor do they transfer automatically to newcomers with few contacts outside the center. According to a survey on asylum seekers' experiences at reception centers $(\mathrm{N}=311), 89 \%$ answered that they felt safe in the center, but at the same time 69\% reported feeling lonely (Koistinen, 2017). Marucco's (2017) study indicates that residents are often only in touch with other asylum seekers and staff, lacking contact with the wider society. Workers at the centers have the power of governance. They somewhat juggle their roles, as at the same time many tasks and duties relate to multifarious forms of care and caring as well as regulation. 


\section{Care, Gender, and Others}

The gendered nature of care and unpaid care at home and work and in other sectors of life has been an important topic in feminist research for decades. This nature impacts not only the segregation of caring work as a "women's work area," but also women's private life, use of time and energy, and career development (Tronto, 1992; Bowlby et al., 2010; Author A). Feminist ethics of care addresses the relationships and responsibilities, the situational, concrete circumstances, and the actual activities of care (Gilligan, 1982). According to Tronto (1993), care implies reaching out to something other than oneself, and it also includes an element of action, where the other person's needs are at the core. Care is a crucial part of human everyday life, but multifaceted power relations are embedded in care, and those who receive care are often interpreted as Others (Tronto, 1993, p. 144). Power-over can take place in care relations.

Ungerson (2006, p. 277) defines caring for as "the practical tasks of care" and caring about as "the affective relations of care." The emotional aspects of care are often understood to be incompatible with masculinities. Gartner, Schwerma, and Beier (2007) suggest that care is not entirely new in men's lives. Calasanti (2003) suggests that care by men often contains greater physical instrumental elements, and thereby care by men remains invisible. Models of a traditional masculine actor are not necessarily compatible with care work, unless they are clearly distanced from caring about, (inter)dependency, love, and tenderness (Anttonen \& Zechner, 2011).

Often in Westernized cultures, dominance, action, achievement, rationality, physical power, and control over one's feelings are set as normative constraints on what is 'masculine', while communality, emotionality, and empathy are seen as 'feminine' (Jokinen, 2010). Boys and men are expected to follow gender norms, which do not necessarily include solidarity with disadvantaged groups (Adams \& Coltrane, 2005). "Care" and "men" are often disconnected-Hearn (2001) notices that the avoidance of care has traditionally been interpreted to be a feature of "being a man," but "[n] urturing can be redefined as normal for boys, young men and men" (Hearn, 2001, p. 17). Yet masculinities are in flux, and for instance, Bridges and Pascoe (2014) argue that the emergence of hybrid masculinities indicates shifts in normative constraints - although these shifts have taken place in ways that perpetuate existing power and inequality regimes. Cottingham (2017) suggests a new masculine ideal of an emotionally adept man emerging in care work, but also warns of the exclusiveness of redefinitions of masculinities; configurations may better be suited to the late modern era's economic premises and be restricted to white, middle-class men.

According to Elliott (2016), 'caring masculinities' already exist in various forms, but these need to be fostered and may be modified. Elliott (2016, p. 252) emphasizes that "the context shape[s] formulation of caring masculinities", and proposes that caring masculinities build on "masculine identities that exclude domination and embrace the affective, relational, emotional, and interdependent qualities of care identified by feminist theorists of care." Bird (1996, p. 126) argues, "Through emotional detachment, the meanings formed in regard to masculinity are exaggerated so as to distinguish clearly that which all men are not, that is, female. The burden for demonstrating difference is on those trying to avoid the default meanings. Difference becomes an aspect of self in which men have a valued investment."

In feminist research, issues of sameness, difference, and the Other have been and are core questions. Otherness is also relevant in research on ethnicity and demarcations of belonging, new racializations, and many more topics in social sciences and critical research. Said's (1978) concept of Orientalism shed light on how Western cultures essentialize those of the East through negative stereotyping and racialize the Other. More recent postcolonial research has brought up how even countries with no 
obvious colonial history, such as Finland, have participated, at least indirectly, "in the production of Europe as the global center and profited from this experience" (Loftsdóttir \& Jensen, 2012, p. 1).The situatedness of the identities and political positions of postcolonial subjects and the differences in experiences as well as material conditions are re-evaluated further in postcolonial feminist approaches (Özkazanç-Pan, 2012). Keskinen (2012) points out how Nordic countries identify their self-image as liberal, gender equal, and progressive countries without a colonialist background, although whiteness remains the main signifier of belonging and national identity. For example, the ignorance of the rights of the indigenous Samí people shows the infamous colonial and current abuses in the Nordic area. The lack of biological markers of 'non-whiteness' often hide the subordinations and marginalization.

The non-whiteness easily becomes a subject of identity politics and issue for racialized processes, i.e. not only a biological marker but as a discriminating and exclusive factor of everyday life (cf. Liu 2018). Hogan (2009, p. 9) highlights that many marginalized groups within a nation who are different from the dominant groups are constructed as 'internal Others' and sometimes represented as threats against order in societies - for instance, through labeling people with non-Finnish backgrounds as dangerous, especially when they are men.

Caring for people who are either close relatives or traditionally seen as entitled to public care, such as children or elderly people, is understood to be either inherent (unpaid care) and/or acceptable as such. On the other hand, caring for those whose "real" need for help is questioned comes under scrutiny. Defining who deserves to be cared for even includes nationalistic features; newcomers who do not have a stable status become more complicated subjects of care-some are "denizens," and some end up as undocumented people, whose numbers are likely to increase after their refugee status in Finland is denied.

Caring constitutes one aspect of working with asylum seekers. Work - be it paid work or voluntary work - can be mentally demanding as well as rewarding in many ways: the work contributes toward helping people with multifaceted experiences of human suffering. The line between paid and volunteer work is not necessarily always clear. Koistinen (2017) emphasizes that there can be tension between different ethnic groups in the centers, which adds to the demanding nature of working/caring. Despite the fact that most residents reported being well treated $(80 \%)$ in the UMRI survey, every third reported omissions in opportunities for leisure time activities and felt insecure in encounters with staff (Koistinen, 2017).

The intersections of ethnicity/race, religion, gender, sexuality, and age impact how the activities at the centers take place. Intersectionality theory, which draws from the experiences of women of color, is used to reconceptualize identities, deconstruct social categories and divisions, and explore multiple marginalizations (bell hooks, 1981; Crenshaw, 1991; Collins, 2015). Instead of a single-axis analysis, intersectionality brings up the simultaneous existence and occurrence of different sociocultural categories, as well as how they mutually construct and transform each other and how oppressions and power relations are reproduced, for instance, in working life contexts (Cho et al., 2013; Liu, 2018).

Work with and care of people with a foreign background contains multifaceted Othering elements. Many of the residents have experiences of severe conditions, violence, and abuse. The presence of the Other-asylum seekers - who need help in their current life stage, but do not necessarily seem helpless, encompass a tension. Public pressures on those who work in reception centers can be manifested through media, social media, and direct communications as hate speech. Local communities or groups of people can have prejudices or feel threatened because of the newcomers. For instance, a common threat that has been discussed relates to assumptions of increased crime, sex crimes in particular (Kelahaara \& Mattila, 2017). 


\section{Methodology, Data, and Analysis}

Our analysis from interviews with workers and volunteers at the reception centers is based on a discourse analytical method. We define discourse as a rather coherent system of meanings which are constructed in language use in its context (Phillips \& Hardy, 2002). Thus, the discourses that bring caring work discursively into being are analyzed (Parker, 1992, p. 5). According to Fairclough (1992), the strength of discourse analysis is that it enables the researcher to study how discourses are not solely descriptions of the social world, but also create and transform social arrangements and ideas. Using language in a specific way both maintains and creates meaning, thereby influencing people's attitudes, thinking, and acting (Fairclough, 1992; Hardy, 2001; Phillips \& Hardy 2002). For instance, caring work can be articulated in a way which emphasizes the traditional ideas of gender order and embedded norms, but can also be an inspiration for the creation of new ideas, such as that men could care more.

To gain a rich and broad view of the topic, we applied a purposeful sampling for this study (Patton, 2002). The data was produced with the help of semi-structured interviews with 23 respondents. We chose respondents who represented both paid employees $(\mathrm{N}=11)$ and volunteers $(\mathrm{N}=12)$ in four reception centers in Finland. Both men $(\mathrm{N}=11)$ and women $(\mathrm{N}=12)^{\mathrm{i}}$ were included, and the interviewees were aged from 20 to 60 . The sites of four different centers further ensured the variety of opinions and the depth of understanding of the phenomenon; data collection took place until the saturation point (see Patton, 2002). The interviews were conducted during the spring of 2016, which was four to eight months after the establishment of the reception centers. The interview outline was constructed along three main topics: the motives for work/volunteering, the challenges encountered, and the gender aspects of work.

Spoken research consent was sought before each interview, and in this process it was explained that confidentiality and anonymity are carefully guaranteed throughout the research process (cf. The Finnish Advisory Board on Research Integrity, 2009). Participation was voluntary, and it was possible to withdraw at any phase of the research process; however, no participants withdrew. The interviews took place in peaceful places according to the choice of the interviewee. Author B was employed at the reception center administration during the time of the interviews. ${ }^{\text {ii }}$ She was a coordinator of the volunteer work and thus a colleague to the managers and workers. This may have caused some bias in the data, as the volunteers might have been careful not to criticize, for instance, the management and organization of the centers. However, many saw the interview as an opportunity to report deficiencies and complain about them. Both paid workers and volunteers seemed to speak freely and expressed their experiences openly and often self-reflectively.

The recorded interviews were transcribed by a professional transcriber. The data was anonymized carefully, and the text was codified through pseudonyms. We read the transcripts in detail, made an initial coding, and then categorized the text according to its content. Next, the categories were classified into broader groups. Each group, taking work and motivation into account, contained a common definition of caring work and gender (cf. Hardy \& Phillips, 2002). After this phase of the preliminary analysis, we approached the groups from the viewpoint of discourse practices to examine the aspects and ideas of the actors and their positions in relation to one another in the texts, and their positions in relation to gender order. Finally, the consequences were detected of particular ways of speaking from the viewpoint of gender order. The analysis process was iterative by nature, requiring extensive discussion among the researchers. As a result of the analysis process, we defined three discourses: the discourse on solidarity and care, the discourse on control and order, and the discourse on caring men. In the following section, these discourses are introduced. 


\section{The Three Discourses}

\section{Discourse on solidarity and care}

The discourse on solidarity and care refers to caring work which reveals the interviewees' feelings of fear and anxiety for the "heart-breaking" destiny of asylum seekers. The most common outspoken motive for doing work and volunteering in reception centers was described to be concern about the vulnerable situations caused by wars and crises, and for the people fleeing from their homes. Reports during 2015 on asylum seekers' situations in the media had roused many of the interviewees to help, as "one needs to do something." Thus, help and solidarity were articulated as being carried out by the volunteers and the women:

Lauren: Anxiety was the feeling that was at the top for me as an over-empathetic and sensitive person ... also fear, but particularly anxiety for those people. (Woman, volunteer, 50s)

This discourse was constructed through self-reflective pondering on what to do, as there "was anxiety for those people," as Lauren stated, and feelings of solidarity and willingness to offer help. On the other hand, the discourse was extended as a counter-reaction to the negative comments and hate speech that emerged in society:

Ben: There were those pictures of drowned people in the Mediterranean Sea. It was not understood that it will concretize also here. Both wondering about and interest in the phenomenon .... and also concerning the hate speech that started and the contradictory reactions ... How you can help the newcomers and also society. (Man, volunteer, 30s; emphasis ours)

In this discourse, the interviewees said that they decided to volunteer in the reception centers to "take a personal stand" in the ongoing heated public debates: "When these counter-reactions started, and it felt like opinions were divided, it felt like one needed to take a stand either pro or against," as Ellie (a woman volunteer in her 30s) explained. However, the situation of those who wanted to help was described as not easy. Throughout the data, the interviewees brought up the emergence and existence of strong racist and xenophobic attitudes toward asylum seekers and those who help them. Nearly all stated that they had encountered questioning of their aid work and, for many, this had been a quite drastic experience as prejudice sometimes originated from people close to them. Many interviewees shared how their keenness to help asylum seekers was reacted to negatively in social media and in everyday encounters with people they knew, and even with strangers.

Ellie: There were those counter-reactions [on asylum seeking]... Instead of yelling on the Internet, I was happy to be able to help in a concrete way, as in the phase of writing my thesis. (Woman, volunteer, 30s)

The respondents positioned themselves not only as responsible citizens whose caring work, in the form of unselfishly helping victimized asylum seekers as their objects of help, is difficult, ambiguous, and demanding. Additionally, the respondents constructed themselves as open-minded people with no negative ideas or behavior, in contrast to hostile outsiders - that is, other Finns with negative attitudes. The interviewees thus made a clear dichotomy between themselves as good and responsible people on the side of vulnerable asylum seekers, and those who have negative attitudes towards them. In other words, the respondents (re)produced a confrontation between themselves and other Finns who do not support and participate in caring work among Others (cf. Hogan, 2009), and avoided 
discussing the refugee phenomenon on some occasions. They said that they purposefully ignored hostile comments, changed their social networks, and even dropped some relationships with friends.

Although the titles and work descriptions of the workers and volunteers were not gender specific, many activities were constructed by the respondents as gendered. In the midst of the eagerness to help in a crisis, gender-equality aspects oddly seemed to evaporate in their speech, and traditional ideas of gender roles were expressed, for example in Hanna's quote that "perhaps men are better at projects or issues where there is a direct goal [assembling of furniture]—women do not lift things." Lauren emphasized that men do 'manly' things with boys that differ from the tasks of women:

Lauren: It is really good that some [men] have taken boys out for winter fishing, and then we [women] try to teach the language here somehow ... and customs. We [women] have talked about Easter and the First of May and other such things. And last time we have taught how to do errands, as many had bought whatever from shops. (Woman, volunteer, 50s; emphasis ours)

The competences of women and men, both of the staff and asylum seekers, were said to differ. The newcomers were expected to commit to traditional gender roles, and for instance, the assumption was that female asylum seekers are interested mainly in handicrafts and tea-time "women's discussions." For men, it was mentioned to be more suitable to be involved in athletic activities (see also Marucco, 2017). Thus, the gendered positions impacted how asylum seekers were constructed as women or men. This was obviously not necessarily intentional, but can be linked to the respondents' ideas and assumptions about other gender orders, and thereby understandings of suitable work or leisure-time activities. One example was football, which some volunteer men mentioned to be actively involved in with asylum seeker men.

Daniel: I play football with them [asylum seeker men] every Friday, and they are so grateful that they can play and that physical exercise is available, so that there are some activities. (Man, volunteer, 60s)

Organizing football activities can be very significant in terms of bringing the different ethnic groups and the workers/volunteers together (Kelohaara \& Mattila, 2017). Paradoxically, it was articulated to be appropriate only for men, which excluded women and (girl) children from physical activities. The benevolent do-gooding thus strengthened the traditional gender order both among the residents and the workers alike.

To summarize, this discourse builds on the willingness to help and an unfaltering solidarity, even when the volunteers were harassed by comments about their own life sphere and the personal sacrifices that they make, such as giving up some of their close relationships and friends. It seems that in unfamiliar crisis situations, gender roles and order remain — or return to - the traditional order, in contrast to current formal gender equality policies. This is strengthened by assuming the gender order of Others to be traditional, and thus it entails a benevolent adaptation to ethnicized gender orders.

\section{Discourse on control and order}

This second discourse is constructed by workers, mainly by paid men workers. It builds on a critique of a "too soft" approach towards asylum seekers and on argumentation for a more assertive approach to caring work that would guarantee control (by the workers) and order in the centers:

Alex: That kind of assertiveness, assertiveness ... which brings [credibility] to this 
workers' responsibility, because we have quite a large responsibility in our work ... so that everyone would understand that all issues should not be suppressed. (Man, worker, $50 \mathrm{~s})$

According to the respondents, control and order are necessary because disputes tend to take place among asylum-seeker men with different cultural and social backgrounds. Disagreements were said often to relate to very practical aspects, such as close quarters and the use of shared spaces (showers, bathrooms) and restrictions on living conditions (bedtime, return time to the center) (cf. Marucco, 2017). Thus, the asylum seekers become positioned as problematic people in their behavior in this discourse. The interviewees' discussion of the refugees also refers to the criticism of the institutionalized structures of (some) centers as well as seeing specific ethnic groups of asylum seekers as a unified group (Kelahaara \& Mattila, 2017). Positions of powerlessness were said to enhance negative reactions among men, and differences in cultural backgrounds were described as having an impact on how the workers would address the situations:

Adam: It is challenging if they [asylum seekers] are, for instance, from [region] countries, and when they speak in loud voices and in a kind of agitated way like they were fighting ... it can be frightening and challenging. (Man, worker, 20s; emphasis ours)

"Speak[ing] in loud voices," as Adam states in his quote, can be understood as disturbing and interpreted as fighting. For instance, in the Somali culture, one of the characteristics of a "real man" is speaking loudly, yet eloquently (Hansen, 2008).

In this discourse, gendered aspects of caring work were raised also as regards physicality: some of the workers were said to tend to lean on their (male) physical appearance to confirm their authoritative position:

Tom: Well, from the point of view of the residents, they really respect you if you are a big and vocal chap! [laughter] ... Professional ... one needs to be professional and not too child-like nor girly in this job, otherwise it can backfire if you are not to the point. (Man, worker, 40s; emphasis ours)

In addition to an impressive "manly" appearance, respect was mentioned as being established by professional, "non-girly" masculine behavior: there is "a need for an assertive, more chappy grip," according to Alex. Whereas the vociferousness of the male residents is considered "challenging" and even "frightening" by the respondents, it is argued to be a necessity and advantage for a (male) worker. This seems to entail the idea that asylum seekers are positioned as 'care objects' in the reception centers and needed to be disciplined or at least controlled by strong and convincing male workers. In fact, naming the workers "instructors," as is done in the reception centers, positions them in an authoritative rather than a caring position. The carriers of this discourse were critical of the working methods used in other caring work sectors, such as in child custody or day-care centers, and wanted other workers and volunteers to "bear the responsibility." Demarcation lines were established between the "manly" workers with a strong grip in contrast to those who are "too soft or weak":

Chloe: Managers are probably professional in their so-called own sectors, but they are not accustomed to foreign cultures and people with these kinds of difficulties, and thereby cannot adapt to [the center's work] ... This is not a child-welfare institution nor a day-care center, and this [lack of competence] is every now and then annoying. (Woman, worker, 50s; emphasis ours) 
Alex positioned himself as a "responsible man" in a controlling role. He complained that "they think that I am a kind of a policeman here, I have a negative sign on my forehead," which had resulted in a situation where "they do not say hello to me anymore." Alex's position distanced him from the Others, as the "police" role is met with fear and/or suspicion in many cultural contexts - in particular in the case of asylum seekers. Notions of cultural differences and interpretations of gender relations are interesting, such as in Lewis's quote: "For instance, they prefer a man interpreter to a woman interpreter. This comes from their culture that women are in a so-called lower position" (Lewis, man, worker, 20s). The critique, as presented also by Tom, is directed toward the cultures of Others, "where they do not value women," whilst the gendered work practices in reception centers and the inequalities within the wider society remained unspoken.

This discourse builds on the logic of the traditional gender order, referring to masculinist protection in caring work by an apparently benign and virtuous man, who safeguards and controls those in subordinate positions in need of protection (cf. Young, 2003). At the same time "the masculinist protection works to elevate the protector to a position of superior authority and to demote the rest of us to a position of grateful dependency" (Young, 2003, p. 3). The traditional understanding of hegemonic masculinity as that of white heterosexual men (cf. Connell, 1987; Hearn, 2015), exemplified by the assertive and strong workers at the centers, is the basis of this discourse. Another nominal part is the difference between "them," those coming from different cultures, and "Finns," including an up-to-down attitude with an added tone of sexism. The discourse implies that one's own presumptions are difficult to discern; gender and ethnic discrimination are easier to notice elsewhere.

\section{Discourse on caring men}

The third discourse is constructed from the rethinking of the role of men in relation to care. Here care refers to a relationship between the asylum seeker and volunteer infused with empathy and the joint concrete work, such as building something together. Additionally, human growth, which working with volunteers can advance, is mentioned by the respondents. In general, care and caring work often remain defined as female areas, that is, a 'feminine/maternal call', as was embedded in the previous discourses. However, this is challenged by an emerging discourse of caring men (see Elliott, 2016), which was mainly carried out by the volunteers.

Ryan: Volunteer work is easily understood as somewhat caring [work] or something that is embedded in women's roles. But, also when we started to paint the walls or to assemble beds, it is actually an issue of care. (Man, volunteer, 60s)

Stereotypes of men as incapable of expressing empathy, especially when the question is about Others' lives, are reconstructed in many of the interviews. Ben raised the issue of an assumed inadequate "capacity for empathy" by Finnish men with a light and rather humorous tone:

Ben: It may be that a Finnish man's incapacity for empathy, in particular men from [area], is not so [hesitates] or it takes place inside four walls, from where one can sometimes send a couple of euros for charity through a mobile phone. But, to throw oneself into being friendly and putting oneself on the spot is perhaps somewhat stranger for men. (Man, volunteer, 30s; emphasis ours)

Ben pointed out how difficult it is to become an activist and helper for "a[n ordinary] Finnish man." Men's (in)capacity for empathizing was pondered from the perspective of the environment and the opposition toward volunteering to work with asylum seekers: 
Chloe: But I believe that women are somehow more empathetic and also have more courage to show that. I do believe that there are also men who are empathetic, but they have perhaps stronger pressure from the environment [not to show empathy], that [a man] has to be somehow tougher to come to work as a volunteer in a reception center. (Woman, worker, 50s; emphasis ours)

The interviewees stressed the concrete work of building, carrying, and painting as care, which reflects the instrumental elements of men's care (Calasanti, 2003). According to the respondents, after an instrumental care/caring phase, there might also be more space for discussion and more relaxed encounters with asylum seekers, as stated by Ryan: "Now we are in a different situation [compared to the start of the center], so that I can also come to hang around and wait to see what happens next."

Daniel explained how he had started his path in volunteering through concrete work tasks, but how he had gotten more deeply involved after having been asked to do more. Thus, concrete work acted as a path to a more intimate and closer relationship between volunteer men and asylum seekers:

Daniel: Then I was asked to be there on call in person, and then I started ... first giving help during the evening shift ... and then acting as a responsible person for the group [asylum seekers] who arrived. ... Thus I have grown into these tasks. (Man, volunteer, 60s; emphasis ours)

In the interview, Daniel said that the development toward getting more involved with aid and care tasks and, in particular, the manifold nature of the tasks also developed him as a person: "So that I have grown as a person," he stated, referring to his more in-depth aid for asylum seekers. He continued:

Daniel: It has become increasingly the case that those who have come here and who aim to find the main thread of a life here have put in really hard effort. Thus it's the result of really hard work, and this really needs all the support that also we volunteers can give. So, it demands a lot from us, also from us [men], so this idea [of aid and care] is strengthened ... I have the feeling that this work is valued ... I have not heard it said of anyone who works here that they would be "womanish." (Man, volunteer, 60s)

In this discourse, having an understanding of the work, as well as of care, is not interpreted as unsuitable for men, but instead it is appreciated as a valued form of work. Daniel's comment that disengages the reception-center (care) work from "womanish" work is contradictory: it embeds an assumption that the activity needs to be manly or at least not womanish to be valued. Ryan pondered that "there [in society] are definitely traditional pictures of manhood, masculinities, and these kinds of gender roles", but these could be gradually changed through (men's) volunteer work.

To summarize this third discourse, men volunteers and asylum seekers become positioned in an actors' position more than in the previous discourses - more as partners in a development process for more personal and equal relationships. Additionally, this discourse emphasizes that volunteer men in reception centers differ from traditional men and masculinities. Consequently, in this discourse gender order becomes challenged.

\section{Summary and Discussion}

Care is strongly gendered at work, in homes, and in personal relationships. Definitions of care, 'caring for', and 'caring about' all have particular contextual gender-specific meanings and aspects. These 
premises are reflected in the care and caring work in reception centers. Finnish working life and society are relatively equal in many respects, but work and care are still persistently segregated into women's and men's areas and tasks, both hierarchically and horizontally (Mikkelä, 2013). In this study, we explored care work and gender by addressing how care is a (re)constructed and gendered process of Finnish working life negotiated in the paid and volunteer work in reception centers for asylum seekers. Our analysis shows possibilities for change. We found three discourses, which are interlinked but also contradictory. We interpret that they all have an impact on gender order and understandings of care/caring work and gender.

Our results are summarized in Table 1.

$* * *$ Insert Table $1 * * *$

The first discourse on solidarity and care is grounded on relatively traditional gender roles, and it stabilizes the current gender order. The heartfelt will to help those in need was actualized, particularly in volunteer work at the centers. In spite of criticism from people outside, many of the actors at reception centers embraced solidarity with the asylum-seeking Others, whose difficult situations motivated the volunteers to continue their helping and caring work. This demanded mundane heroism, which is traditionally connected to acts by men and masculinities. In this discourse women took the role of 'mothering carers', who taught the Finnish language, were active with children, or introduced the residents to Finnish culture. In spite of the bravery of the actions of those who wanted to help, this first discourse somewhat oddly reproduced the traditional gender order and supported the ethnicization and Othering of the residents.

The second discourse on control and order is the most stable and solid: traditional gender roles are appreciated, and the bipolarity of genders is strong. Power and power-over are understood to be important in reception centers and perhaps more broadly as well. This discourse gains from Othering, and it (ab)uses gender equality in framing embedded xenophobic attitudes to be those of necessityorder is needed to control the suspicious flow of "fortune seekers" and potential perpetrators of sexual and gender-based violence against (Finnish) women. It is noteworthy that the carriers of this discourse were only the wageworkers, mainly men. This discourse reconstructs most clearly the predominant gender order, where care is outsourced as the responsibility of women and where the dominant masculinity of white heterosexual men undermines other groups of men (and women).

The third discourse we found is that of caring men. This discourse somewhat contests traditional gender roles and emphasizes the possibility of a collaborative approach toward and encounters with asylum seekers. It brings up new kinds of men and masculinities. 'Caring about' is emerging in this discourse as something that men are gradually more and more capable of doing and are willing to participate in. We echo Elliott (2016, p. 249), who suggests that "it does not matter if men do not care about initially because when men care for, they can begin to develop the affective, emotional aspects of care." The forms of work at the centers are not necessarily understood as care, but the actual work includes an extensive amount of caring. The contradictory element is that gender roles are still somewhat bipolar and men's roles in caring thereby need to be explained and distanced from "womanish" work. However, this discourse enables caring masculinities to emerge in the context of the reception centers. Another contradiction is that the increase in care work by men seems to take place at the snail's pace of formal policies, such as efforts to desegregate working markets; instead, care by men might evolve through actual experiences of care work in somewhat different contexts, such as working with asylum seekers. 
Although care work often refers to childcare, elderly care, or to care that takes place in schools through education, it can include work in other institutions (for instance, prisons) or emergency help. Such care work has a heroic label and is more male dominated than "mundane" care jobs or work in reception centers. Yet Cottingham (2017) emphasizes that economic shifts, including an increase in care-sector jobs, may enhance a new masculine ideal of emotionally adept men.

To conclude, the findings of our study show that traditional attitudes towards gender are easily discerned in other cultures, but not so easily recognized in the everyday processes near at hand. Gender order is retained through traditional roles, which also reflect conventional attitudes in the studied society, Finland, which is often seen as a model country for gender equality. However, change is possible, and one core issue is the need to involve men in care work and caring in general. As the data is qualitative and was produced through purposeful sampling, generalizations about the impacts of, for example, age and care perspectives would not be reliable. In Finland both women and men work mostly full-time, which can diminish the opportunities to participate in voluntary caring work in the hectic mid-career time. On the other hand, young people and seniors can enhance the caring work done by men: young men may be more conscious of the changes needed, and older men may not need to emphasize a traditional understanding of the incompatibility of men and care (cf. Hearn, 2001).

As we concentrated on the workers and volunteers at the reception centers, the voice of the residents is not heard directly, which is a limitation in this study. Thus there is a need for future research on the asylum seekers' perspectives on the work in the centers as regards to gender, gender order, and masculinities. In the reception centers' context, the need for care by residents who are men, in particular non-married, able-bodied, and young, is questioned. This does not enhance but impedes men's care and caring role; instead, they are expected to protect women and children from dangerous Others. Thus, the current structures and discursive processes can be relevant for an understanding of the gendered care and work in the centers, and thereby be of use for empowering current or future residents at the centers.

\section{References}

Adams, M., and Coltrane, S. (2005), "Boys and Men in Families: The Domestic Production of Gender, Power, and Privilege." In M. S. Kimmel, J. Hearn, and R. W. Connell (eds.) Handbook of Studies on Men and Masculinities, 230-248. Thousand Oaks, Calif: Sage Publications.

Anttonen, A., and Zechner, M. (2009), “Theorising Care and Care Work.” In B. Pfau-Effinger, and T. Rostgaard (eds.) Care Between Work and Welfare in European Societies, 15-34. Hampshire: Palgrave MacMillan.

Bassel, L. and Emejulu, A. (2018), Minority Women and Austerity: Survival and Resistance in France and Britain. University of Bristol: Policy Press.

bell hooks (1981), Ain't I a Woman? Black Women and Feminism. Boston: South End Press.

Bird, S. R. (1996) "Welcome to the Men's Club: Homosociality and the Maintenance of Hegemonic Masculinity." Gender \& Society 10:120-132.

Bowlby, S., McKie, L., Gregory, S., and MacPherson, I. (2010), Interdependency and Care Over the Lifecourse. Oxon: Routledge. 
Bridges, T. and Pascoe, C.J. (2014), "Hybrid Masculinities: New Directions in the Sociology of Men and Masculinities." Sociology Compass 8(3): 246-258.

Butler, J. (1990), Gender Trouble: Feminism and the Subversion of Identity. New York: Routledge.

Campbell, L. D., and Carroll, M.P. (2007), "The Incomplete Revolution. Theorizing Gender When Studying Men Who Provide Care to Aging Parents.” Men and Masculinities 9:491-508.

Calasanti, T. (2003), "Masculinities and Care Work in Old Age." In S. Arber, K. Davidson, and J. Ginn (eds.) Gender and Ageing. Changing Roles and Relationships, 15-30. Maidenhead: Open University Press.

Cho, S. K., Crenshaw, K. and McCall, L. (2013), “Toward a field of intersectionality studies: Theory, applications, and praxis." Signs: Journal of Women in Culture and Society, 38(4): 785-810.

Collins, P. H. (2015), “Intersectionality's definitional dilemmas.” Annual Review of Sociology, 41: $1-20$.

Connell, R.W. (1987), Gender and Power. Stanford, CA: Stanford University Press.

Cottingham, M.D. (2017), "Caring moments and their men: masculine emotion practice in nursing." NORMA: International Journal for Masculinity Studies 12:270-285.

Crenshaw, K. W. (1991), "Mapping the margins: intersectionality, identity politics, and violence against women of colour." Stanford Law Review, 43(6):1241-1299.

Elliott, K. (2016), "Caring masculinities. Theorizing and emerging concept". Men and Masculinities 19(3): 240-259.

Fairclough, N. (1992), Discourse and Social Change. Cambridge, UK: Polity Press.

The Finnish Advisory Board of on Research Integrity (2009), "Ethical principles of research in the humanities and social and behavioural sciences and proposals for ethical review", http://www.tenk.fi/en (accessed 31.8.2018).

Gartner, M., Schwerma, K., and Beier, S. (2007), Fostering Caring Masculinities. Documentation of the German Gender Expert Study. Berlin, Germany: Dissens e.V. and genderWerk.

Gilligan, C. (1982), In a Different Voice: Psychological Theory and Women's Development. Cambridge, MS: Harvard University Press.

Hanlon, N. (2012), Masculinities, Care and Equality. Identity and Nurture in Men's Lives. Hampshire: Palgave McMillan.

Hansen, P. (2008), "Circumcising Migration: Gendering Return Migration among Somalilanders." Journal of Ethnic and Migration Studies 34:1109-1126.

Hardy, C. (2001), "Researching Organizational Discourse." International Studies of Management and Organization 31:25-47. 
Hearn, J. (2001), "Men and Gender Equality: Resistance, Responsibilities and Reaching Out." Keynote at the Conference Men and Gender Equality, Örebro, Sweden, March 15-16.

Hogan, J. (2009), Gender, Race and National Identity. Nations of Flesh and Blood. New York: Routledge.

Jauhiainen, J.S. (2017), “Johdanto ja johtopäätökset.” In J.S. Jauhiainen (ed.) Turvapaikka Suomesta? Vuoden 2015 turvapaikanhakijat ja turvapaikkaprosessit Suomessa., 5-18. Publications of the Department of Geography and Geology of University of Turku. Turku: University of Turku.

Jokinen, A. (2010), “Kriittinen mies- ja maskuliinisuustutkimus.” In T. Saresma, L-M. Rossi, and T. Juvonen (eds.) Käsikirja sukupuoleen, 128-139. Tampere: Vastapaino.

Kelahaara, M., and Mattila, M. (2017), “Onneen ei ole oikotietä tässä maassa. Kauhava ja Kauhavan vastaanottokeskus”. Julkaisuja 10. Turku: Siirtolaisuusinstituutti.

Keskinen, S. (2012), "Limits to Speech? The Racialised Politics of Gendered Violence in Denmark and Finland." Journal of Intercultural Studies 33: 261-274.

Keskinen, S. and Andreassen, R, (2017), "Developing Theoretical Perspectives on Racialisation and Migration.” Nordic Journal of Migration Research, Special Issue Editorial, 7(2): 64-69.

Koistinen, L. (2017), "Vastaanottokeskukset, onnistuneet käytännöt ja turvapaikanhakijoiden kokemukset." In J.S. Jauhiainen (ed.) Turvapaikka Suomesta? Vuoden 2015 turvapaikanhakijat ja turvapaikkaprosessit Suomessa 49-64. Publications of the Department of Geography and Geology of University of Turku. Turku: University of Turku.

Liu, H. (2018), “Re-radicalising intersectionality in organisation studies.” Ephemera, 18(1): 81101.

Loftsdóttir, K. and Jensen, L. (eds.) (2012), Whiteness and postcolonialism in the Nordic Region: Exceptionalism, migrant others and national identities. Farnham: Ashgate.

Marucco, C. (2017), “Turvapaikanhakijoiden arkipäivä.” In J.S. Jauhiainen (ed.) Turvapaikka Suomesta? Vuoden 2015 turvapaikanhakijat ja turvapaikkaprosessit Suomessa, 85-101. Publications of the Department of Geography and Geology of University of Turku. Turku: University of Turku.

Migri (2017a), Vastaanottotoiminnan tilastot. http://www.migri.fi/tietoa_virastosta/tilastot (accessed 26.6.2017).

Migri (2017b) [The Finnish Immigration Service], Reception services. http://www.migri.fi/asylum_in_finland/reception_activities/reception_services (accessed 28.9.2017).

Mikkelä, E. (2013), “Naisten ja miesten ammatit ja työt.”. In M. Pietiläinen (ed.) Työ, talous ja tasaarvo, 65-82. Helsinki: Statistics Finland.

Ministry of the Interior (2017), Usein kysytyt kysymykset turvapaikanhakijoista. http://intermin.fi/maahanmuutto/turvapaikanhakijat-ja-pakolaiset/ukk (accessed 28.9.2017).

Parker, M. (1992), Discourse Dynamics. London: Routledge. 
Patton, M.Q. (2002). Qualitative research and evaluation methods. Thousand Oaks, CA: Sage.

Phillips, N. and Hardy, C. (2002), Understanding discourse analysis. Thousand Oaks, CA: Sage.

Pringle, K. (1995), Men, Masculinities, and Social Welfare. London: ULC Press.

Schippers, M. (2007), "Recovering the feminine other: Masculinity, femininity, and gender hegemony", Theory and Society, 36, 85-102.

Said, E. (1978). Orientalism. London: Routledge and Kegan Paul.

Tronto, J. (1993), Moral Boundaries: A Political Argument for an Ethic of Care. New York: Routledge.

Ungerson, C. (2006), "Gender, Care, and the Welfare State." In K. Davis, M. Evans, and J. Lorber (eds.) Handbook of Gender and Women's Studies, 272-86. London: Thousand Oaks, MA; New Delhi: Sage.

Young, I. M. (2003), "The Logic of Masculinist Protection: Reflections on the Current Security State." Signs: Journal of Women in Culture and Society 29: 1-25.

World Economic Forum (2017), The Global Gender Gap Report 2017 http://www3.weforum.org/docs/WEF_GGGR_2017.pdf (accessed 31.8.2018).

Özkazanç-Pan, B. (2012), "Postcolonial feminist research: Challenges and complexities." Equality, Diversity and Inclusion: An International Journal, 31(5/6): 573-591.

\footnotetext{
'We are aware that the categories of "women" and "men" have limitations, and that there are also other genders, but these did not come up in the positioning of the interviewees themselves. In addition, we address questions of sexuality and heteronormativity (for instance, Butler 1990) only in passing in this paper.

ii Author B was at the time working in the administration of the centers.
} 